WORKING PAPER \#434

INDUSTRIAL RELATIONS SECTION

PRINCETON UNIVERSITY

MARCH, 2000

http://www.irs.princeton.edu/pubs/working_papers.html

The Digital Divide in Educating African-American Students and Workers

Alan B. Krueger*

Princeton University and NBER

October 19, 1999

Revised: February 28, 2000

*This paper was prepared for the Joint Center for Political and Economic Studies conference on "Education and Training for the Black Worker in the 21st Century". The paper was written while Alan Krueger was on leave at the Center for Advanced Study in the Behavioral Sciences at Stanford University. He is grateful to Melissa Rekas for excellent research assistance, to Cece Conrad, Susan Williams McElroy, and Margaret Simms for helpful comments, and to the Center for Advanced Study in the Behavioral Sciences, the Joint Center for Political and Economic Studies, and the Princeton University Industrial Relations Section for financial support. 


\title{
Executive Summary \\ The Digital Divide in Educating African-American Students and Workers
}

\author{
Alan B. Krueger \\ Princeton University and NBER
}

As Bill Bradley recently observed, "A pair of strong hands are not what they used to be. Now those hands have to be able to use a keyboard." In 1997, over half of all workers directly used a computer keyboard on the job. Workers who use a computer at work are paid more than those who do not, and are more highly sought after by employers. The Commerce Department's 1999 report, Falling Through the Net: Defining the Digital Divide, highlighted that African-American workers are less likely than others to have access to information technology at home and at work. The Commerce Department report did not address the issue of training African-American students and workers to use computer technology. This paper seeks to fill that void by exploring the magnitude of the racial divide in the use of computer technology among school children, and considering the consequences of the digital divide. The key findings are summarized below.

- Data from the October Current Population Survey (CPS) School Enrollment Supplement in 1984, 1989, 1993 and 1997 are the main source of data on computer use in school analyzed in the paper. This survey asked a national sample of students living in 55,000 households: "Do you directly use a computer at school?" Direct use of a computer was defined as hands on use of a computer that involves using a computer keyboard, and computers could include personal computers, laptops, mini computer or mainframe computers. Results are summarized in Table 1. According to the CPS data, there has been rapid growth in the use of computers in school since the mid 1980s. In 1984, fewer than one third of all students reported using a computer in school, and by 1997 more than three-quarters of all students reported using a computer in school. Computer use is more prevalent among elementary school students than high school students.

- Looking at all grades combined, Table 1 shows that Black students were 16 percentage points less likely than White students to use a computer in school in 1984, and only 6 percentage points less likely in 1997. The Black-White gap in school-based computer use has historically been larger in grades 1-8 than in high school. The figures in Table 1 indicate that the Black-White gap in the proportion of students who use a computer in school completely disappeared by 1997 for high school students, although a 10 point gap remains in grades 1-8.

- Hispanic students were more likely to use computers in school than Black students from 1984 through 1993, but in 1997 Hispanic students were 5 points less likely than Black students to use computers in school. As a consequence, the Hispanic-White gap in computer use is now larger than the Black-White gap in computer use.

- Data from the 1997 CPS were also used to tabulate the percentage of students from different racial backgrounds who report using the Internet in school. African-American students are less likely to use the Internet than are White students. And the gap in Internet use is greatest at the high school level: 27.4 percent of White high school students use the Internet at school, 
compared to 19.1 percent of Black students. As with overall computer use, the gap in Internet use is even greater between White and Hispanic students than it is between Black and White students. Black and Hispanic students seem to lag behind in using the latest technology in school, and their teachers seem to lag behind in their preparation to use the latest technology.

- Differences in computer use can arise for many reasons, including differences in geographic location, urbanicity, and family income among members of different racial groups. Ordinary Least Squares regressions were estimated to adjust for various factors that are associated with a higher incidence of computer use in school in 1984, 1989, 1993, and 1997. In all years, income and region of residence were found to be particularly important factors in accounting for the Black-White gap in computer use at school. About half of the observed Black-White gap in computer use can be attributed to differences in family income, demographic characteristics, grade level, and region of residence. The remaining half of the gap may result because: (1) the schools that are predominantly attended by minority students lack resources to purchase computers, even after adjusting for students' family income; (2) teachers in schools that are attended by minority children lack adequate preparation to use computers; (3) teachers of minority students may prefer to teach with traditional methods instead of computers because they think such methods are more efficacious for their students.

- African-American children are much less likely to live in households that own computers, and less likely to use computers at home. A tabulation of the October 1997 CPS indicates that 51 percent of White students age 6-18 regularly use a computer at home, while only 21 percent of Black students do so. The Black-White gap in computer use at home is greater for high school students than it is for elementary and middle school students. Among those who use a computer at home, Black students are less likely to use the computer for educational programs than are White students ( 48 versus 40 percent), and less likely than White students to use the computer to complete school assignments (64 versus 58 percent).

- Despite the rapid increase in computer use at school, there is surprisingly little compelling scientific evidence on the efficacy of Computer Assisted Instruction (CAI). Much of the evidence is old and out of date, and only one study has used a randomized design. Nonetheless, my reading of the evidence is that Computer Assisted Instruction, when done correctly, can help reinforce traditional classroom learning. But the curriculum has to be tailored to the students' needs with clear goals in mind, and CAI may be ineffective, or perhaps harmful, if done incorrectly. Discerning cause from effect in the observational studies of computer use and student achievement is nearly an insurmountable challenge for researchers. The time is past due for Department of Education to fund a large-scale, randomized study of the impact of computerassisted instruction to determine which modes of CAI work best, and for which types of students.

- Several studies have found that workers who possess computer skills tend to fare better in the labor market than seemingly identical workers who lack computer skills. Krueger (1993) found that workers who use a computer on the job are paid approximately 15 percent more, on average, than other workers in the same industry who have the same level of education and experience, 
but do not use a computer on the job. In a survey of over 3,000 employers in Atlanta, Boston, Detroit, and Los Angeles, Holzer (1996; 1995) found that 51 percent of newly filled jobs for noncollege graduates require computer use on a daily basis, and 74 percent of newly filled jobs for college graduates require computer use on a daily basis. Boozer, Krueger and Wolkon (1992) find that students who used computers in high school are more likely to obtain higher paying jobs early in their career that involve some computer use. Although there is legitimate debate among economists as to why workers who have computer skills fare better in the job market, the author argues that a reasonable interpretation of the evidence is that providing workers who are computer illiterate with computer skills would significantly raise their job prospects and income.

- Black workers are considerably less likely to use computers on the job than are White workers. In 1997, 52 percent of White workers directly used a computer on the job, and only 40 percent of Black workers did so. When they use computers on the job, Black workers tend to use them for similar tasks as White workers, although Black workers are less likely than White workers to use computers to perform multiple tasks.

- Lastly, the paper considers what can be done to narrow the digital divide in access to information technology. Further reducing the racial divide in training to use information technology will require a concerted effort and greater investment in technology for schools. There is also a need to develop and distribute instructional materials that are geared to the minority community. Because most current workers learned how to use a computer at work, rather than in school, it is also important to expand access to on-the-job training for minority workers. And it might be possible to reach out to groups that traditionally have had little access to information technology, such as those in jail and prison, to try to prepare them for the digital economy. 


\section{The Digital Divide in Educating African-American Students and Workers}

"A pair of strong hands are not what they used to be. Now those hands have to be able to use a keyboard."

Senator Bill Bradley

October 7, 1999

\section{Introduction}

As Bill Bradley recently observed, the American job market is increasingly connected to information technology. In 1997, over half of all workers directly used a computer keyboard on the job. Workers who use a computer in their daily routine are paid more than those who do not, and are more highly sought after by employers.' The Commerce Department's 1999 report, Falling Through the Net: Defining the Digital Divide, highlighted the fact that African-American families are less likely than others to have access to information technology at home and at work. This paper explores the racial divide in the use of computer technology among school children. Computers in school are used for substantive instruction (e.g., learning the times tables), are used to search for information, and are used to prepare students for using information technology once they enter the job market. The goal of this paper is to measure the extent of the digital divide in computer-related training in elementary and secondary schools, and to evaluate the likely consequences of the digital divide.

Schools can be a powerful force for bridging the divide in access to information technology; they can also reinforce existing gaps between African Americans and members of other races. The next section reviews evidence on the "racial divide" in computer use in school. The results indicate that African-American school children are less likely to use computers in

'See Krueger (1993), Holzer (1996), and Autor, Katz and Krueger (1998). 
school, although the gap has narrowed considerably in the 1980s and 1990s. A 10 percentage point Black-White gap in computer use remains in the elementary school grades, while in 1997 Black and White high school students were equally likely to use computers in school. Black students are also less likely to use the Internet in school than are White students, and this gap is larger for high school students than for elementary and middle school students.

Section 2 considers evidence on the efficacy of computer technology in achieving educational goals. Despite the rapid increase in computer use at school, there is surprisingly little compelling scientific evidence documenting that computer technology raises student achievement levels. Section 3 reviews evidence of the link between computer-related skills and success in the job market. Evidence suggests that workers who have computer skills have much better job prospects than those who lack such skills. It is still an open question, however, whether employers seek out, and highly reward, workers who have computer skills because they value those skills, or because computer competence is correlated with other desirable worker attributes. The conclusion offers suggestions for narrowing the digital divide.

\section{1: The Digital Divide in Computer Use at School}

Several studies have documented a racial gap in information technology in schools. Some studies evaluate data on the number of computers or Internet connections in schools, disaggregated by the racial composition of the schools' students, whereas others evaluate student-level data on computer usage in school. The previous research primarily has focused on the 1980s.

Most of the previous research has found lower utilization or prevalence of computers in 
schools predominantly attended by Black students. ${ }^{2}$ Based on the National Survey of School Uses of Microcomputers conducted by the Center for Social Organization at Johns Hopkins between December 1982 and March 1983, for example, Becker (1985) found that students who attended a school with a high concentration of non-White students had a higher ratio of students to computers than schools with a high ratio of White students. Based on Johns Hopkins's Second National Survey of 2,331 public and private schools conducted in the Spring of 1985, Becker and Sterling (1987) also found that schools with a higher percentage of non-White students were less likely to have any computers used by students, and the gap was larger at the elementary school (K-6) level. A third Johns Hopkins survey conducted in 1989 also found that schools with a high concentration of non-White children had fewer computers per student, especially at the elementary grades (see Anderson, et al., 1994). The 1989 survey found that elementary schools with less than one quarter minority students had 28.6 students per computer, while schools with a majority of non-White students had 39.4 students per computer; for upper secondary schools the corresponding ratios of students per computer were 25.6 for predominantly White schools and 24.8 for predominantly non-White schools.

Boozer, Krueger and Wolkon (1992) examined student-level data on computer use from the 1984 and 1989 October Current Population Surveys (CPS), and found that Black and Hispanic students were less likely to use computers in school than were White students. The gap was larger at the elementary school grades, and narrowed to only 4 percentage points in

${ }^{2}$ One prominent study which did not find a racial gap in computer use in school was done by the University of Minnesota for the National Science Foundation, and based on the 1981-82 National Assessment of Science, which included a national random sample of 18,000 students age 9, 13 and 17 (see McPhail, 1985). 
grades 9-12 in 1989.

A recent study by Harold Wenglinsky (1998) calculates the frequency of computer use based on data on fourth and eighth graders from the 1996 National Assessment of Educational Progress (NAEP) in mathematics, and evaluates the impact of computer use on students' math test scores. The computer use data analyzed by Wenglinsky from the NAEP questionnaire are self-reported by the students, like the CPS data. A unique advantage of the NAEP data is that they also contain teacher-reported information on the teachers' previous computer preparation, and information on the type of use of computers (e.g., simulations, applications, drills, and practice). Wenglinsky only looks at use of computers for math. Contrary to most of the previous literature, Wenglinsky finds that Black fourth grade students are more likely to use computers at school at least once a week than are White students (42 versus 32 percent). Wenglinsky also finds that Black eighth graders are more likely to use a computer at least once a week for math applications than are White eighth graders, but this differential is statistically insignificant (33 versus 28 percent). It is unclear whether peculiarities of the NAEP data generate this result, or whether Black students are more likely to use computers in school than White students. On the basis of no direct evidence on the impact of public policy, however, Wenglinsky concludes, "It seems that policies to promote computer access in school have succeeded in eliminating inequities of this sort [access to computer technology]." On the other hand, Wenglinsky finds that, "Disadvantaged groups do seem to be less likely to have teachers well-prepared to use computers," and that compared to White students, "Blacks are less likely to use computers for applications and more likely to use them for drill and practice."

Table 1 extends the previous literature by calculating the percent of students who directly 
use a computer in school by race and Hispanic ethnicity, in selected years between 1984 and 1997. (Hispanic students can be of any race.) The table is based on data from the October Current Population Survey. In 1984, 1989, 1993 and 1997, the School Enrollment Supplement to the October CPS contained a set of questions on computer use. The main question of interest is: "Do you directly use a computer at school?" Direct use of a computer was defined as hands on use of a computer that involves using a computer keyboard, and computers could include personal computers, laptops, mini computer or mainframe computers. ${ }^{3}$ Two noteworthy advantages of the CPS data are that the computer use question is consistent over time, and the data are collected for a large, nationally representative samples. A potential disadvantage of the survey data is that proxy responses were accepted. To generate the estimates in Table 1, weighted percentages of students who use a computer in school were calculated, where the weights are the CPS final weights. Standard errors and sample sizes for the estimates are reported in Appendix Table 1a and 1b, respectively.

The results in Table 1 indicate a tremendous increase in the use of computers in school since the mid 1980s. In 1984, fewer than one third of all students reported using a computer in school, and by 1997 more than three-quarters of all students reported using a computer in school. Computer use is more prevalent among elementary school students than high school students. Looking at all grades combined, Black students were 16 percentage points less likely than White students to use a computer in school in 1984, and only 6 points less likely by 1997 . Consistent

${ }^{3}$ Respondents were told that for purposes of the survey, computer use excluded "handheld calculators or games, electronic video games, notepads, WebTV, or systems which do not use a typewriter-like keyboard." 
with findings in most of the previous literature, the Black-White gap in this measure of computer use has historically been larger in grades $1-8$ than in high school. Indeed, the figures in Table 1 indicate that the Black-White gap in the proportion of students who use a computer in school completely disappeared by 1997 for high school students, while a 10 point Black-White gap remains for students in grades 1-8. Hispanic students were more likely to use computers in school than Black students from 1984-93, but in 1997 Hispanic students were 5 points less likely than Black students to use computers in school. As a consequence, the Hispanic-White gap in computer use is now larger than the Black-White gap in computer use.

The 1997 CPS data also contained a question on the frequency with which computers are used in school. According to these data, three quarters of the students who use a computer at school use it every day or several times a week; only 5 percent use a computer less frequently than once a week. If we follow Wenglinsky and define computer use as using a computer at least once per week, the racial gaps that are apparent in Table 1 are slightly smaller, but still substantial. For example, in 1997 some 77.7 percent of White students in grades 1-8 use a computer at least once a week, while 68.7 percent of Black students use a computer at least once a week. If we look just at fourth graders with the CPS data, Black students are 10 percentage points less likely than White students to use a computer at least once a week in school (85 versus 75 percent), contrary to Wenglinsky's finding that Black fourth graders are 10 points more likely to use a computer based on the NAEP data.

Simply using a computer is a crude measure of the extent of information technology used in schools. This measure misses the intensity with which computers are used, as well as the purpose and efficacy of computer use. The 1997 CPS asked respondents: "Do you use the 
INTERNET (or another on-line service) at school?" Table 2 reports the percentage of students from different racial backgrounds who report using the Internet in school. African-American students are less likely to use the Internet than are White students. And the gap in Internet use is greatest at the high school level: 27.4 percent of White high school students use the Internet at school, compared to 19.1 percent of Black students. The gap is even greater between White and Hispanic students than it is between Black and White students.

Differences in computer use can arise for many reasons, including differences in geographic location, urbanicity, and family income among members of different racial groups. To examine the racial gap in computer use further, Table 3 reports Ordinary Least Squares estimates of linear probability models using the $1984 \mathrm{CPS} .{ }^{4}$ The dependent variable in these models is a dummy variable that equals one if the student uses a computer in school, and zero if he or she does not. In the first column, only race and Hispanic ethnicity are held constant. White students are the base group. In column 2 , additional controls are included to hold constant the students' sex, grade, age and public or private school attendance. Column 3 further controls for the region the student resides in, city type, and city size. Finally, column 4 additionally controls for 14 dummy variables indicating ranges of the student's family income.

The regression results reported in column 1 indicate that in 1984 Black students were 17

${ }^{4}$ Logit models yielded results that were quite similar to the linear probability models, so the linear probability models were reported for simplicity. Because all of the explanatory variables in the model are dummy variables, it is not surprising that the logits and the linear probability models are similar. 
percentage points less likely than White students to use a computer in school. ${ }^{5}$ As another example, the results in column 4 indicate that girls are 2 percentage points less likely to use a computer in school than boys, after controlling for the effects of race, public school attendance, grade level, age, family income, and the other explanatory variables listed in the table. The full set of controls included in the model in column 4 account for almost half of the Black-White gap in school-based computer use. Income and region of residence are particularly important factors in accounting for the Black-White gap in computer use. Nonetheless, about a 9 point BlackWhite gap in computer use remains after all the variables in column 4 are held constant. The effects of some of the other variables in Table 3 are also of interest: girls are slightly less likely to use computers in school than are boys; students who are in a higher grade for their age level are more likely to use computers, while students who are old for their grade are less likely to use computers; and although it is not shown in the table, students from high- income families are more likely to use computers in school than are students from low-income families.

Tables 4, 5 and 6 provide the corresponding regression results using the 1989, 1993, and 1997 October CPS's. In these later years, the coefficient estimates are generally similar to those for 1984 (or at least of the same sign), although one notable change is that students in the South became more likely to use computers than those in the West in the 1990s. Most importantly for our purposes, the same pattern emerges in that controlling for family income and regional characteristics accounts for almost half of the Black-White gap in computer use.

${ }^{5}$ The coefficient on the Black indicator variable is not equal to the difference between the Black and White proportions using a computer in Table 1 because Hispanic students can be of any race, so the variables are not mutually orthogonal. 
What might account for the Black-White gap in computer use that remains after adjusting for differences in family income, demographic characteristics, grade level, and region? Several factors could be at work. First, schools that are predominantly attended by minority students could lack resources to purchase computers, even conditional on the students' family income. Second, teachers in schools that are attended by minority children could lack the training or background to use computers. Alternatively, teachers of minority students may prefer to teach with traditional methods instead of computers because they think such methods are more beneficial for their students. The fact that the Black-White gap in computer use in school has eroded for high school students suggests that differences in teacher competencies and resources have been overcome in high schools.

A final issue concerns the use of computers at home. African-American children are much less likely to live in households that own computers, and less likely to use computers at home. A tabulation of the October 1997 CPS indicates that 51 percent of White students age 618 directly use a computer at home, while only 21 percent of Black students do so. And the Black-White gap in computer use at home is greater for high school students than it is for elementary and middle school students. The gap in computer use is only partially accounted for by the lower average income of African-American families. Tabulations from the CPS data further indicate that, among students who use a computer at home, Black students are less likely to use the computer for educational programs than are White students (48 versus 40 percent), and less likely than White students to use the computer to complete school assignments (64 versus 58 
percent). ${ }^{6}$ It is possible that the racial gap in computer use in school is a partial manifestation of the gap in computer use at home: children who are not exposed to computers at home may feel less comfortable using them in school than children who are exposed to computers at home. Regardless of the source of the digital divide, African-American children are exposed to computer technology less often than White children are at home and at school. The next sections consider the consequences of this digital divide for academic achievement and job market success.

\section{Educational Consequences of the Computer Use Gap}

There is surprisingly little compelling evidence on the efficacy of Computer Assisted Instruction (CAI). In part, the problem arises because technology is changing so quickly. Different studies evaluate different hardware and software products, and by the time the study is completed the technology is often obsolete. In addition, virtually all studies of computers and student learning are based on observational data. A common problem with studies based on observational data is that it is virtually impossible to control adequately for all the factors that affect student achievement and that might be correlated with the use of computers. Randomized, controlled experiments overcome this problem. Only one randomized experiment that I am aware of has been conducted on the effect of CAI, and that was done in the late 1970s with a fairly small sample. In addition, computer-based instruction could affect several outcomes to varying degrees, and some studies focus on different outcomes, further clouding conclusions.

${ }^{6}$ The figures for use of educational computer programs are just for those age 6-14 in 1997. 
The study that utilized random assignment is described in Ragosta, Holland and Jamison (1982). This study was conducted by the Educational Testing Service (ETS) with funding from the National Institute of Education in the Los Angeles Unified School District. As part of the experiment, four elementary schools were equipped with computer labs using terminals and printers operated by a minicomputer, for 3.5 years beginning in the Spring of 1977. Computer assisted instruction was provided by drill and practice curriculums in math, reading and language arts. The software was leased from Computer Curriculum Corporation of Palo Alto, California. Students were randomly assigned to receive or not receive CAI curriculum as part of the study's research design. Students were tested with the Iowa Tests of Basic Skills (ITBS) and the Comprehensive Tests of Basic Skills (CTBS), as well as curriculum-based tests. The results were encouraging. After three years, the average student who undertook CAI math instruction scored in the 76th percentile of the control group on the CTBS computation test, 54th percentile on the CTBS concepts test, and 60th percentile on the CTBS applications test. ${ }^{7}$ The average student who received CAI instruction in reading scored better than the average student in the control group, but the gap was only statistically significant in the first year. The ETS experiment was based on a small sample (usually fewer than 200 students in the treatments and controls), and the technology is now dated. It is unclear whether the results apply to students today. But a great advantage of the ETS study is that, in principle, the randomized design ensured that extraneous factors that are correlated with computer use and student achievement (e.g., family income) did not confound the results.

\section{test, however.}

${ }^{7}$ The treatment-control difference was only statistically significant on the computation 
Another study that devotes a good deal of attention to potential spurious factors that might be correlated with the prevalence of computer use and student achievement was conducted by Angrist and Lavy (1999), based on data from Israel. Angrist and Lavy exploit variations in the adoption of computers caused by the Tomorrow-98 program, which abruptly and significantly upgraded the computer technology in several schools. Between 1994 and 1996, some 905 schools received 35,000 computers and teacher instruction as a result of the Tomorrow-98 program. Schools were selected for computer installation based on an application process that gave priority to towns with a high proportion of 7th and 8th grade enrollment in stand-alone middle schools. Angrist and Lavy conclude: "The results reported here do not support the view that CAI improves learning, at least as measured by pupil test scores. Using a variety of estimation strategies, we find a consistently negative relationship between the program-induced use of computers and fourth grade math scores." It is unclear, however, whether the bleak results for Israel apply to American students, and to the instructional software packages that are commonly used in American schools. Nonetheless, the design of Angrist and Lavy's analysis could potentially be applied in the U.S. In particular, district- or state-level policies that rapidly phase in technology in some schools in a way that is unrelated to students' characteristics and abilities could potentially be used to evaluate the effect of those technologies on student achievement.

As mentioned, a large-scale study of the impact of computer use on the academic achievement of American students was recently conducted by Wenglinsky (1998). This study received much attention in the press. Wenglinsky modeled students' tests scores on the fourth and eighth grade NAEP Mathematics exam as a function of their frequency of computer use in 
school, type of computer application, class size, socio-economic status, and teachers' characteristics. Although it is hard to determine the exact statistical model that Wenglinsky estimated, it is clear that his findings are mixed. The frequency of school-based computer use was negatively associated with test scores for both fourth and eighth graders. That is, students who reported using a computer more frequently tended to score lower on the NAEP exam. But some particular uses of computers had a positive effect on test scores in his estimates. Computer use for applications and simulations was positively associated with test scores, whereas use of computers for drills and practice was negatively associated with test scores. One concern with these results is that they may spuriously reflect a tendency of teachers to use more basic applications when they have weaker students in their class, rather than reflect any direct effect of the technology. No one would be surprised if teachers tended to use traditional drill and practice exercises (e.g., flash cards) with eighth grade students when those students were low-achievers, or if teachers emphasized applications of the integral calculus when their students were high achievers. But one would be reluctant to ascribe causality as running from the teaching method to student achievement in these situations. In a similar fashion, the causality could run from students in need of remedial help to basic drill and practice computer applications, rather than from basic computer applications causing a decline in tests.

Several meta-analyses on the effect of computer use on student achievement have been conducted. ${ }^{8}$ These studies try to synthesize the underlying estimates in the literature. The metaanalyses tend to find that computer use is positively associated with student achievement. For

${ }^{8}$ See Cuban and Kirkpatrick (1998) for a summary of the meta-analyses on this topic, and several individual studies. 
example, Kulik and Kulik (1991) collected 254 past controlled studies of the effectiveness of computer-based instruction, and concluded that, "In $202(81 \%)$ of the studies, the students in the CBI class had the higher examination average; in $46(19 \%)$ of the studies, the students in the conventionally taught class had the higher average." Of course, a meta-analysis can only be as convincing as the combined strength of the underlying studies in the literature. If, as in the case of computer use, reverse causality is a problem (e.g., more advantaged students tend to use computers), then a meta-analysis is unlikely to be very informative unless the underlying studies have dealt adequately with the reverse causality problem (which most have not). After reviewing several meta-analyses, single studies, and critical reviews, Cuban and Kirkpatrick conclude, "we are unable to ascertain whether computers in classrooms have in fact been or will be the boom they have promised to be."

My reading of the evidence is that computer assisted instruction, when done correctly, can probably help reinforce traditional class room learning. But the curriculum has to be tailored to the student with clear goals in mind, and CAI may be ineffective, or perhaps harmful, if done incorrectly. Discerning cause from effect in the observational studies of computer use and student achievement is nearly an insurmountable challenge for researchers. As I have written elsewhere, the time is past due for the Education Department to conduct a large-scale, randomized study of the efficacy of computer-assisted instruction to determine which modes of CAI work best, and for which types of students. In the meantime, we putter around with highly imperfect information.

\section{Job market and Computer Literacy}


Workers who use a computers on the job tend to be paid more than other workers in the same industry who have the same level of education and experience, but do not use a computer on the job (see Krueger, 1993). Moreover, temporary help firms report that, if two workers are otherwise identical, except that one has computer skills and the other does not, they would pay considerably more to the worker with computer skills (Krueger, 1993). In a recent survey of over 3,000 employers in Atlanta, Boston, Detroit, and Los Angeles, Harry Holzer (1996) inquired as to which types of tasks are performed by newly hired employees. For non-college graduates, he found that 51 percent of newly filled jobs require daily computer use. He also found that a large number of other cognitive tasks were performed in these jobs on a daily basis, including doing arithmetic (65 percent), reading paragraphs ( 55 percent) and writing paragraphs (30 percent). For college graduates, Holzer (1995) found that 74 percent of new hires were required to perform computer tasks on a daily basis.

In earlier work, I have leaned towards a causal interpretation of the earnings-computeruse relationship. That is, I suspect that if workers who are currently unable to use computers are trained to use them, their wages will increase, on average. In addition, based on Holzer's survey work, I would suspect that workers trained to use computers would also experience less difficulty finding a job (i.e., unemployment would decline).

DiNardo and Pischke (1997) question my causal interpretation of the wage premium associated with using a computer on the job. They do so by estimating earnings functions similar to the ones I estimated for the U.S. using data for Germany. First they show that the coefficient on a dummy variable indicating computer use at work is similar in magnitude in Germany and the U.S. Next, they show that a dummy variable measuring such activities as using a pencil at 
work has an effect on earnings that is similar in magnitude to the computer premium if the pencil-use dummy variable is included in the wage equation instead of the computer-use dummy variable. Because they presume pencil use has a spurious effect on earnings, they conclude that one needs to be wary that computer use at work also has a spurious effect. This paper serves as a useful reminder that causality cannot be established absent an experiment or well identified structural model and theory. But at the same time, one has to be aware that a spurious relationship also cannot be established absent an experiment or well identified structural model and theory. For example, the effect of computer use on pay may not be spurious even if the effect of pencil use on pay is spurious, and similar in magnitude to the computer premium. ${ }^{9}$ Equally importantly, when DiNardo and Pischke control for both computer use and pencil use simultaneously in a wage regression using their most recent data, they find that computer use continues to have a substantial impact on pay, but pencil use has a statistically and economically insignificant effect. To the extent that pencil use controls for omitted factors such as inherent cognitive ability, it is computer use that seems to matter for pay and not these other variables. This finding would seem to reinforce a causal interpretation of the effect of computer skills on pay. Finally, even if computer use does spuriously pick up the effect of other variables (e.g., inherent ability) in the German labor market, it is unclear whether computer training would be of no help in the United States labor market. Nonetheless, DiNardo and Pischke are right to emphasize that a causal interpretation of the effect of possessing computer skills on pay is based

${ }^{9}$ Or put another way, if pencils have a spurious effect on pay, why not conclude that education, experience, and all the other variables in the wage equation also have a spurious effect? 
on circumstantial evidence, and has not been proven beyond a shadow of a doubt.

Boozer, Krueger and Wolkon (1992) find that students who used computers in high school are more likely to obtain jobs early in their career that involve some computer use. Specifically, our analysis used data on 7,016 high school graduates in 1980 or 1982 who were observed in the labor market in 1984, based on a sample drawn from the High School and Beyond Survey. Workers who used a computer in high school as part of their educational training were 7.6 percentage points more likely to use a computer at work than those who did not use a computer in high school, after controlling for such factors as the students' year of high school graduation, race, sex, age, marital status, grade point average, cognitive test scores, region of residence, and parent's education. Because only 18.4 percent of workers in this sample used a computer at work, having taken a course that involved using a computer in high school raised the odds of using a computer on the job substantially. It is unclear, however, whether this elevated use of computers at work was directly influenced by the fact that students were exposed to computers in high school, or whether some other factor is responsible for both the students' use of computers in high school and on the job. For example, students with an inherent interest in technology may be drawn to use computers in high school and on the job, and they might still obtain high-paying jobs that use computers even if they did not have the opportunity to learn about computers while they were in school. Distinguishing causality in this instance would seem to be a priority for further research.

The role of computer skills in influencing individuals' job prospects and pay is of particular importance to the African-American community because, as Table 7 shows, Black workers are considerably less likely to use computers on the job than are White workers. In 
1997, 52 percent of White workers directly used a computer on the job, and only 40 percent of Black workers did so. The Commerce Department's 1999 report further shows that minorities are much less likely to have access to computers and the Internet at work and at home. If possessing computer skills, and having access to information technology, are important entrytickets to a high paying job, then fewer Black workers can gain entrance.

Table 8 reports the types of tasks that workers use computers to perform, by race and Hispanic origin. The sample is restricted to the subset of workers who use a computer on the job. A worker could report multiple tasks, so the sum of the percentages exceeds 100 percent. Interestingly, the general pattern of computer use across these tasks is similar across racial groups, although Black workers report a lower percentage of use on every task. This phenomenon arises because, when they use a computer on the job, Black workers tend to use the computer for fewer tasks than White workers.

\section{Conclusion}

A great irony of the digital divide is that computers and information technology have tremendous potential to create a color blind society. Neither the seller nor buyer of a product over the WEB knows the race, sex or ethnicity of the other party involved in the transaction, and nor do they care. An Internet search engine designed to seek out the lowest price of a product does not take race, sex or ethnicity into account. Alas, advanced technology can also exacerbate existing divisions and inequalities in society if minority groups lack the resources, training and access to social networks that are required to participate in the digital economy.

What can be done to narrow the digital divide in access to information technology? First, 
it should be noted that some progress has been made. The decline in the Black-White gap in the use of computers in elementary and middle schools -- and its elimination in high school -- are positive developments. But the more recent opening of a Black-White gap in the use of the Internet is a worrisome development. Black students seem to lag behind in using the latest technology in school, and their teachers seem to lag behind in their preparation to use the latest technology. If the pace of technological change in education hastens, the digital divide in training students will likely widen.

An obvious proposal to try to narrow the digital divide is to invest more to expand training and access to information technology. As Commerce Secretary Daley has argued, "Ensuring access to the fundamental tools of the digital economy is one of the most significant investments our nation can make." To some extent, such an investment is taking place, but so far the investment has not been adequate to bridge the gap in school resources, teacher preparation, and disparities in home resources, and to keep pace with the rapid pace of technological change. It also seems to me that there is a need to develop and distribute instructional materials that are geared to the minority community. For example, as an outgrowth of his senior thesis at U.C. Berkeley, in 1992 Eno Essien wrote and self-published an excellent and widely used manual titled, The Black Computer Survival Guide, which illustrated the use of key computer software with examples specifically developed for the minority community. More current manuals of this sort could help spread interest in, and use of, information technology in minority communities.

Simply expanding access to technology will not be maximally effective, however, unless progress is made on research on the effectiveness of the use of classroom computer-based technology for student achievement and employment outcomes. The following four areas strike 
me as priorities for government supported research on the digital divide. First, the Department of Education (or other organizations) could conduct an experiment in which a set of schools is randomly selected to receive computer equipment, software, and funds to train teachers in the use of CAI technology, and another set of schools is randomly selected to serve as a control group. After a period of time, the achievement of students in these two sets of schools can be compared. Since all schools are not being provided with computer equipment under present circumstances, using a randomized assignment procedure to provide equipment to some schools would seem particularly fair and feasible in this instance. And such an approach would have the added benefit of yielding far more compelling scientific evidence on the effectiveness of CAI than is currently available from observational research studies. Second, and related, it would be desirable to have more evidence on which types of CAI applications works best for which types of students. In particular, what are the CAI applications -- and educational techniques more generally -- that are most effective for minority and disadvantaged students?

Third, more analysis is required to understand why the racial gap in computer use at school exists. For example, is the source of the gap a lack of funds to purchase equipment in schools heavily attended by minority students, or is it because teachers in these schools lack proper training in CAI so that the equipment is unused? Understanding the reasons for the digital divide is obviously important if public policy is to effectively bridge the divide. Fourth, more analysis is required to learn whether there is a causal link between computer-based education and students' subsequent outcomes in the labor market. It is possible that the digital divide at work stems from workplace policies and practices (e.g., racial discrimination) which are beyond the reach of narrow educational policy focused on technology. 
Most workers learned how to use a computer on the job, since the technology was in a nascent stage when they were in school. One issue to consider is the role of social networks in allocating workers to jobs, and therefore workers to on-the-job training. Even for non-college jobs, Holzer (1996) finds that social networks are an important aspect of job placement: 26 percent of newly-hired non-college employees were recruited for their job via a referral by a current employee. Minority workers are under-represented in positions that use computers, and this may be a barrier to gaining entry into jobs and networks where workers are trained to use computers. If this is the case, then encouraging firms to cast a broader net in recruiting employees could expand access to information technology. In addition, temporary help firms are a major source of training on computers (Autor, 1999), and often a path to a permanent job. Alerting individuals of available training opportunities, such as those provided by temporary help firms, could also help expand access to information technology.

Finally, nearly two million Americans are currently in jail or prison. This population is over 90 percent male, and over 45 percent of those in jail or prison are Black. ${ }^{10}$ Only a small proportion of individuals who are incarcerated work while they are in prison or jail. And a distressingly low proportion of individuals who have been incarcerated work in the formal economy when they are released from jail or prison. It might be possible to reach out to this group to try to prepare them for a meaningful career when they are released from prison. Indeed, there have been some exemplary cases in which prisoners were introduced to information technology in a meaningful way. For example, the Detwiler Foundation has worked with prisons

${ }^{10}$ See Bureau of Justice Statistics Bulletins: Prison and Jail Inmates at Midyear 1998, table 7, and Prisoners in 1998, table 11. 
to train prison laborers to refurbish obsolete computers that were donated by corporations. ${ }^{11}$ After the prisoners have upgraded the computers, they are donated to schools -- a win-win situation. Successfully bridging the digital divide may require similar creative solutions.

"Information about the Detwiler Foundation is available from the following WEB address: <http://wwwnt.thegroup.net/detwiler/>. 


\section{References}

Anderson, Ronald, Vicki Lundmark, Linda Harris, Shon Magnan, "Equity in Computing," in Chuck Huff and Thomas Finholt (eds.), Social lssues in Computing, New York: McGraw-Hill, Inc., 1994.

Angrist, Joshua and Victor Lavy, "New Evidence on Classroom Computers and Pupil Learning," mimeo., MIT, Cambridge, MA, May 1999.

Autor, David H., "Why do Temporary Help Firms Provide Free General Skills Training?" unpublished dissertation chapter, Harvard University, 1999.

Autor, David, Lawrence Katz, and Alan Krueger, "Computing Inequality: Have Computers Changed the Labor Market?" Quarterly Journal of Economics, 113, No. 4, November 1998, pp. 1169-1213.

Becker, Henry, "How Schools Use Microcomputers: Summary of the 1983 National Survey." Second National Survey of Instructional Uses of School Computers. Baltimore, MD: The Johns Hopkins University.

Becker, Henry and Carleton Sterling, "Equity in School Computer Use: National Data and Neglected Considerations," Journal of Educational Computing Research, 3, No. 3,1987, pp. 289311.

Boozer, Michael, Alan Krueger, and Shari Wolkon, "Race and School Quality Since Brown vs. Board of Education," (with), in Brookings Papers on Economic Activity: Microeconomics, Martin N. Baily and Clifford Winston (eds.), 1992, pp. 269-326.

Cuban, Larry, and Heather Kirkpatrick, "Computers Make Kids Smarter -- Right?" Technos 7, (2), Summer 1998, pp. 26-31.

DiNardo, John and Jorn-Steffen Pischke, "The Returns to Computer Use Revisited: Have Pencils Changed the Wage Structure Too?” Quarterly Journal of Economics, February, 1997.

Holzer, Harry, What Employers Want. New York: Russell Sage Foundation, 1996.

Holzer, Harry, "Employer Skill Needs and Labor Market Outcomes," mimeo., East Lansing, Michigan State University, September 1995.

Krueger, Alan, "How Computers Have Changed the Wage Structure: Evidence From Microdata, 1984-1989," Quarterly Journal of Economics, 108, No. 1, February 1993, pp. 33-61.

Kulik, Chen-Lin and James Kulik, "Effectiveness of Computer-Based Instruction: An Updated 
Analysis," Computers in Human Behavior, vol. 7, 1991, pp. 75-94.

McPhail, Irving, "Computer Inequities in School Uses of Microcomputers: Policy Implications," Journal of Negro Education, 54, No. 1, 1985, pp. 3-13.

Ragosta, Marjorie, Paul Holland, and Dean Jamison, "Computer-Assisted Instruction and Compensatory Education: The ETS/LAUSD Study," Final Report, Princeton, NJ, Educational Testing Service, April 1982.

United States Commerce Department, National Telecommunications and Information Administration, Falling Through the Net: Defining the Digital Divide, Washington D.C., July 1999.

Wenglinsky, Harold, "Does it Compute? The Relationship Between Educational Technology and Student Achievement in Mathematics," Policy Information Center, Research Division, Educational Testing Service, Princeton, NJ, September 1998. 
Table 1: Percent of Students Using a Computer in School, By Race and Hispanic Origin

$\begin{array}{lrrrr} & 1984 & 1989 & 1993 & 1997 \\ \text { All Grades } & & & & \\ \text { All Races } & 31.3 & 51.2 & 66.3 & 77.0 \\ \text { White } & 33.7 & 53.6 & 68.4 & 78.4 \\ \text { Black } & 17.9 & 39.3 & 56.5 & 72.1 \\ \text { Asian } & \mathrm{n} / \mathrm{a} & 46.8 & 62.4 & 71.1 \\ \text { American Indian } & \mathrm{n} / \mathrm{a} & 56.5 & 69.8 & 74.1 \\ \text { Hispanic } & 20.2 & 41.5 & 58.1 & 67.7\end{array}$

\section{Grades 1-8}

$\begin{array}{lrrrr}\text { All Races } & 32.7 & 54.4 & 69.2 & 79.6 \\ \text { White } & 35.7 & 57.8 & 71.9 & 81.5 \\ \text { Black } & 16.7 & 38.2 & 56.9 & 72.0 \\ \text { Asian } & \mathrm{n} / \mathrm{a} & 48.0 & 63.3 & 74.3 \\ \text { American Indian } & \mathrm{n} / \mathrm{a} & 57.8 & 71.8 & 79.2 \\ \text { Hispanic } & 19.6 & 42.1 & 59.1 & 68.8 \\ & & & & \\ \text { Grades 9-12 } & & & & \\ \text { All Races } & 28.5 & 43.4 & 59.2 & 71.5 \\ \text { White } & 29.8 & 43.6 & 59.8 & 71.8 \\ \text { Black } & 20.5 & 42.2 & 55.5 & 72.6 \\ \text { Asian } & \mathrm{n} / \mathrm{a} & 43.7 & 59.9 & 64.7 \\ \text { American Indian } & \mathrm{n} / \mathrm{a} & 52.5 & 62.8 & 64.8 \\ \text { Hispanic } & 21.7 & 39.5 & 55.6 & 65.1\end{array}$

Sample includes all children aged 6-18 in grades 1-12, and excludes students classified as "other" race and excludes students with a missing value for computer use in school. Hispanics may be of any race. Source: Author's calculations from the October CPS. The CPS final weights were used to calculate the percentages. See Appendix Table $1 \mathrm{a}$ and $1 \mathrm{~b}$ for standard errors and sample sizes. 
Table 2: Percent of Students Using the Internet in School, October 1997

All Grades
All Races
White
Black
Asian

American Indian

Hispanic

\section{Grades 1-8}

All Races

White

Black

Asian

American Indian

Hispanic

Grades 9-12

All Races

White

Black

Asian

American Indian

Hispanic

Percent
19.45
20.52
14.81
16.84
21.66
11.76

16.49

17.27

12.79

15.21

20.31

9.99

25.69

27.38

19.13

20.20

24.12

15.85

\section{Standard Error}

0.30

0.30

0.60

1.30

1.97

0.60

0.30

0.30

0.70

1.47

2.30

0.70

0.50

0.60

1.30

2.40

3.70

1.30
Sample Size

22,435

18,109

3,023

868

435

2,639

15,332

12,352

2,089

591

300

1,880

Sample includes all children aged 6-18 in grades 1-12 and excludes all classified as "other" race. Hispanics may be of any race. Percentages were calculated as weighted averages, using the CPS final weight as weights. Source: Author's calculations from October 1997 CPS. 
Table 3: Linear Probability Model for Computer Use, 1984

Dependent variable: One if uses computer in school, zero if not

\begin{tabular}{|c|c|c|c|c|}
\hline \multirow{3}{*}{ Intercept } & 1 & 2 & 3 & 4 \\
\hline & 0.352 & 0.493 & 0.444 & 0.490 \\
\hline & $(0.003)$ & $(0.026)$ & $(0.030)$ & $(0.034)$ \\
\hline \multirow{2}{*}{$\begin{array}{l}\text { Black } \\
\text { (1=yes) }\end{array}$} & -0.172 & -0.165 & -0.121 & -0.088 \\
\hline & $(0.008)$ & $(0.008)$ & $(0.009)$ & $(0.009)$ \\
\hline \multirow{2}{*}{$\begin{array}{l}\text { Hispanic } \\
\text { (1=yes) }\end{array}$} & -0.147 & -0.139 & -0.116 & -0.087 \\
\hline & $(0.011)$ & $(0.011)$ & $(0.011)$ & $(0.011)$ \\
\hline \multirow{2}{*}{$\begin{array}{l}\text { Female } \\
\qquad(1=y e s)\end{array}$} & & -0.022 & -0.022 & -0.020 \\
\hline & & $(0.006)$ & $(0.006)$ & $(0.006)$ \\
\hline \multirow{2}{*}{$\begin{array}{l}\text { Public school } \\
\text { (1=yes) }\end{array}$} & & -0.041 & -0.043 & -0.025 \\
\hline & & $(0.010)$ & $(0.010)$ & $(0.010)$ \\
\hline \multirow[t]{2}{*}{ Grade } & & 0.028 & 0.022 & 0.013 \\
\hline & & $(0.005)$ & $(0.005)$ & $(0.005)$ \\
\hline \multirow[t]{2}{*}{ Age } & & -0.024 & -0.018 & -0.011 \\
\hline & & $(0.004)$ & $(0.004)$ & $(0.004)$ \\
\hline \multirow{2}{*}{$\begin{array}{c}\text { Northeast } \\
\text { (1=yes) }\end{array}$} & & & -0.004 & 0.001 \\
\hline & & & $(0.010)$ & $(0.010)$ \\
\hline \multirow{2}{*}{$\begin{array}{l}\text { Midwest } \\
(1=y e s)\end{array}$} & & & 0.028 & 0.036 \\
\hline & & & $(0.009)$ & $(0.009)$ \\
\hline \multirow{2}{*}{$\begin{array}{l}\text { South } \\
\qquad(1=y e s)\end{array}$} & & & -0.095 & -0.091 \\
\hline & & & $(0.009)$ & $(0.009)$ \\
\hline \multirow{5}{*}{$\begin{array}{l}3 \text { SMSA type } \\
\text { dummies included } \\
2 \text { SMSA size } \\
\text { dummies included } \\
14 \text { income category } \\
\text { dummies included }\end{array}$} & & & & \\
\hline & no & no & yes & yes \\
\hline & no & no & yes & ves \\
\hline & & & & \\
\hline & no & no & no & yes \\
\hline
\end{tabular}

Notes: Sample size is 25,046 . Standard errors are shown in parentheses. Omitted race group is white. Hispanics may be of any race. Sample restricted to children age 6-18, in grades 1-12. Sample excludes individuals with missing values for computer use in school or classified as "other race". SMSA type includes central city, balance of SMSA, non-SMSA and not identifiable (omitted category). SMSA size categories are: not identifiable, 1-3 million, greater than 3 million (ommitted category). Income categories are: less than $\$ 5,000,5,000-7,499$ $7,500-9,999,10,000-12,499,12,500-14,999,15,000-17,499,17,500-19,999,20,000-24,999$, $25,000-29,999,30,000-34,999,35,000-39,999,40,000-49,999,50,000-74,999,75,000$ or higher (omitted category), and income not reported. 
Table 4: Linear Probability Model for Computer Use, 1989

Dependent variable: One if uses computer in school, zero if not

\begin{tabular}{|c|c|c|c|c|}
\hline \multirow{3}{*}{ Intercept } & 1 & 2 & 3 & 4 \\
\hline & 0.553 & 0.790 & 0.832 & 0.740 \\
\hline & $(0.004)$ & $(0.028)$ & $(0.033)$ & $(0.036)$ \\
\hline \multirow{2}{*}{$\begin{array}{l}\text { Black } \\
\text { (1=yes) }\end{array}$} & -0.157 & -0.153 & -0.114 & -0.085 \\
\hline & $(0.009)$ & $(0.009)$ & $(0.010)$ & $(0.010)$ \\
\hline \multirow{2}{*}{$\begin{array}{l}\text { Asian } \\
\qquad(1=y e s)\end{array}$} & -0.084 & -0.088 & -0.058 & -0.050 \\
\hline & $(0.019$ & $(0.019)$ & $(0.020)$ & $(0.020)$ \\
\hline \multirow{2}{*}{$\begin{array}{l}\text { American Indian } \\
\text { (1=yes) }\end{array}$} & 0.017 & 0.024 & 0.031 & 0.058 \\
\hline & $(0.032)$ & $(0.032)$ & $(0.032)$ & $(0.032)$ \\
\hline \multirow{2}{*}{$\begin{array}{l}\text { Hispanic } \\
\text { (1=yes) }\end{array}$} & -0.134 & -0.132 & -0.095 & -0.068 \\
\hline & $(0.010)$ & $(0.010)$ & $(0.011)$ & $(0.011)$ \\
\hline \multirow{2}{*}{$\begin{array}{l}\text { Female } \\
\qquad(1=y e s)\end{array}$} & & -0.007 & -0.007 & -0.006 \\
\hline & & $(0.006)$ & $(0.006)$ & $(0.006)$ \\
\hline \multirow{2}{*}{$\begin{array}{l}\text { Public school } \\
\text { (1=yes) }\end{array}$} & & -0.020 & -0.023 & -0.011 \\
\hline & & $(0.011)$ & $(0.011)$ & $(0.011)$ \\
\hline \multirow[t]{2}{*}{ Grade } & & 0.026 & 0.025 & 0.018 \\
\hline & & $(0.005)$ & $(0.005)$ & $(0.005)$ \\
\hline \multirow[t]{2}{*}{ Age } & & -0.033 & -0.032 & -0.026 \\
\hline & & $(0.005)$ & $(0.005)$ & $(0.005)$ \\
\hline \multirow{2}{*}{$\begin{array}{c}\text { Northeast } \\
\text { (1=yes) }\end{array}$} & & & 0.047 & 0.049 \\
\hline & & & $(0.011)$ & $(0.011)$ \\
\hline \multirow{2}{*}{$\begin{array}{l}\text { Midwest } \\
\qquad(1=y e s)\end{array}$} & & & 0.033 & 0.036 \\
\hline & & & $(0.010)$ & $(0.010)$ \\
\hline \multirow{2}{*}{$\begin{array}{l}\text { South } \\
\qquad(1=\text { yes })\end{array}$} & & & -0.040 & -0.036 \\
\hline & & & $(0.010)$ & $(0.010)$ \\
\hline \multirow{5}{*}{$\begin{array}{l}3 \text { MSA type } \\
\text { dummies included } \\
7 \text { MSA size } \\
\text { dummies included } \\
14 \text { income category } \\
\text { dummies included }\end{array}$} & & & & \\
\hline & no & no & yes & yes \\
\hline & & & & \\
\hline & no & no & yes & yes \\
\hline & no & no & no & yes \\
\hline
\end{tabular}

Notes: Sample size is 24,291 . Standard errors are shown in parentheses. Omitted race group is white. Hispanics may be of any race. Sample restricted to children age 6-18, in grades 1-12. Sample excludes individuals with missing values for computer use in school or classified as "other race". SMSA type includes central city of MSA, not in center city but in MSA, not in MSA, and not identified (omitted category). SMSA size categories are: not identified, 100,000-249,999, 250,000-499,999, 500,000-999,999, 1-2.499 million (omitted), 2.5-4.999 million, 5-9.999 million, and greater than 10 million. Income categories are: less than $\$ 5,000,5,000-7,499,7,500-9,999,10,000-12,499,12,500-14,999,15,000-19,999$ $20,000-24,999,25,000-29,999,30,000-34,999,35,000-39,999,40,000-49,999,50,000-59,999$ $60,000-74,000$, and 75,000 or higher (omitted category), and income not reported. 
Table 5: Linear Probability Model for Computer Use, 1993

Dependent variable: One if uses computer in school, zero if not

\begin{tabular}{|c|c|c|c|c|}
\hline & 1 & 2 & 3 & 4 \\
\hline \multirow[t]{2}{*}{ Intercept } & 0.699 & 0.880 & 0.777 & 0.676 \\
\hline & $(0.004)$ & $(0.026)$ & $(0.030)$ & $(0.033)$ \\
\hline \multirow{2}{*}{$\begin{array}{l}\text { Black } \\
\text { (1=yes) }\end{array}$} & -0.132 & -0.129 & -0.102 & -0.077 \\
\hline & $(0.008)$ & $(0.008)$ & $(0.009)$ & $(0.010)$ \\
\hline \multirow{2}{*}{$\begin{array}{l}\text { Asian } \\
\quad(1=\text { yes })\end{array}$} & -0.074 & -0.077 & -0.038 & -0.036 \\
\hline & $(0.018)$ & $(0.018)$ & $(0.018)$ & $(0.018)$ \\
\hline \multirow{2}{*}{$\begin{array}{l}\text { American Indian } \\
\text { (1=yes) }\end{array}$} & 0.004 & 0.001 & 0.010 & 0.027 \\
\hline & $(0.035)$ & $(0.035)$ & $(0.035)$ & $(0.035)$ \\
\hline \multirow{2}{*}{$\begin{array}{l}\text { Hispanic } \\
\text { (1=yes) }\end{array}$} & -0.115 & -0.114 & -0.063 & -0.040 \\
\hline & $(0.010)$ & $(0.010)$ & $(0.011)$ & $(0.011)$ \\
\hline \multirow{2}{*}{$\begin{array}{l}\text { Female } \\
\qquad(1=y e s)\end{array}$} & & -0.001 & -0.002 & -0.001 \\
\hline & & $(0.006)$ & $(0.006)$ & $(0.006)$ \\
\hline \multirow{2}{*}{$\begin{array}{l}\text { Public school } \\
\text { (1=yes) }\end{array}$} & & -0.024 & -0.029 & -0.013 \\
\hline & & $(0.011)$ & $(0.011)$ & $(0.011)$ \\
\hline \multirow[t]{2}{*}{ Grade } & & 0.012 & 0.015 & 0.009 \\
\hline & & $(0.005)$ & $(0.005)$ & $(0.005)$ \\
\hline \multirow[t]{2}{*}{ Age } & & -0.020 & -0.023 & -0.018 \\
\hline & & $(0.004)$ & $(0.005)$ & $(0.005)$ \\
\hline \multirow{2}{*}{$\begin{array}{c}\text { Northeast } \\
\text { (1=yes) }\end{array}$} & & & 0.042 & 0.043 \\
\hline & & & $(0.010)$ & $(0.010)$ \\
\hline \multirow{2}{*}{$\begin{array}{l}\text { Midwest } \\
\text { (1=yes) }\end{array}$} & & & 0.035 & 0.037 \\
\hline & & & $(0.010)$ & $(0.010)$ \\
\hline \multirow{2}{*}{$\begin{array}{l}\text { South } \\
\qquad(1=\text { yes })\end{array}$} & & & 0.005 & 0.008 \\
\hline & & & $(0.009)$ & $(0.009)$ \\
\hline \multirow{5}{*}{$\begin{array}{l}3 \text { MSÁ type } \\
\text { dummies included } \\
7 \text { MSA size } \\
\text { dummies included } \\
14 \text { income category } \\
\text { dummies included }\end{array}$} & & & & \\
\hline & no & no & yes & yes \\
\hline & & & & \\
\hline & no & no & yes & yes \\
\hline & no & no & no & yes \\
\hline
\end{tabular}

Notes: Sample size is 23,521 . Standard errors are shown in parentheses. Omitted race group is white. Hispanics may be of any race. Sample restricted to children age 6-18, in grades 1-12. Sample excludes individuals with missing values for computer use in school or classified as "other race". SMSA type includes central city of MSA, not in center city but in MSA, not in MSA, and not identified (omitted category). SMSA size categories are: not identified, 100,000-249,999, 250,000-499,999, 500,000-999,999, 1-2.499 million (omitted), 2.5-4.999 million, 5-9.999 million, and greater than 10 million. Income categories are: less than $\$ 5,000,5,000-7,499,7,500-9,999,10,000-12,499,12,500-14,999,15,000-19,999$ $20,000-24,999,25,000-29,999,30,000-34,999,35,000-39,999,40,000-49,999,50,000-59,999$ $60,000-74,000$, and 75,000 or higher (omitted category), and income not reported. 
Table 6: Linear Probability Model for Computer Use, 1997

Dependent variable: One if uses computer in school, zero if not

\begin{tabular}{|c|c|c|c|c|}
\hline \multirow[b]{2}{*}{ Intercept } & 1 & 2 & 3 & 4 \\
\hline & $\begin{array}{l}0.805 \\
(0.003)\end{array}$ & $\begin{array}{l}0.968 \\
(0.024)\end{array}$ & $\begin{array}{l}0.872 \\
(0.029)\end{array}$ & $\begin{array}{l}0.822 \\
(0.031)\end{array}$ \\
\hline \multirow{2}{*}{$\begin{array}{l}\text { Black } \\
\qquad(1=y e s)\end{array}$} & -0.081 & -0.080 & -0.064 & -0.045 \\
\hline & $(0.008)$ & $(0.008)$ & $(0.008)$ & $(0.009)$ \\
\hline \multirow{2}{*}{$\begin{array}{l}\text { Asian } \\
\qquad(1=\text { yes })\end{array}$} & -0.092 & -0.093 & -0.048 & -0.046 \\
\hline & $(0.014)$ & $(0.014)$ & $(0.015)$ & $(0.015)$ \\
\hline \multirow{2}{*}{$\begin{array}{l}\text { American Indian } \\
\text { (1=yes) }\end{array}$} & -0.044 & -0.039 & -0.035 & -0.023 \\
\hline & $(0.024)$ & $(0.024)$ & $(0.024)$ & $(0.024)$ \\
\hline \multirow{2}{*}{$\begin{array}{l}\text { Hispanic } \\
\text { (1=yes) }\end{array}$} & -0.125 & -0.127 & -0.084 & -0.064 \\
\hline & $(0.008)$ & $(0.008)$ & $(0.009)$ & $(0.009)$ \\
\hline \multirow{2}{*}{$\begin{array}{l}\text { Female } \\
\qquad(1=y e s)\end{array}$} & & -0.012 & -0.013 & -0.012 \\
\hline & & $(0.006)$ & $(0.006)$ & $(0.006)$ \\
\hline \multirow{2}{*}{$\begin{array}{l}\text { Public school } \\
\text { (1=yes) }\end{array}$} & & -0.004 & -0.014 & -0.004 \\
\hline & & $(0.010)$ & $(0.010)$ & $(0.010)$ \\
\hline \multirow[t]{2}{*}{ Grade } & & 0.015 & 0.020 & 0.017 \\
\hline & & $(0.004)$ & $(0.004)$ & $(0.004)$ \\
\hline \multirow[t]{2}{*}{ Age } & & -0.021 & -0.026 & -0.024 \\
\hline & & $(0.004)$ & $(0.004)$ & $(0.004)$ \\
\hline \multirow{2}{*}{$\begin{array}{c}\text { Northeast } \\
\text { (1=yes) }\end{array}$} & & & 0.039 & 0.040 \\
\hline & & & $(0.009)$ & $(0.009)$ \\
\hline \multirow{2}{*}{$\begin{array}{l}\text { Midwest } \\
\text { (1=yes) }\end{array}$} & & & 0.067 & 0.067 \\
\hline & & & $(0.009)$ & $(0.009)$ \\
\hline \multirow{2}{*}{$\begin{array}{l}\text { South } \\
\text { (1=yes) }\end{array}$} & & & 0.042 & 0.044 \\
\hline & & & $(0.008)$ & $(0.008)$ \\
\hline \multicolumn{5}{|l|}{3 MSA type } \\
\hline \multirow{4}{*}{$\begin{array}{l}\text { dummies included } \\
6 \text { MSA size } \\
\text { dummies included } \\
14 \text { income category } \\
\text { dummies included }\end{array}$} & no & no & yes & yes \\
\hline & no & no & yes & yes \\
\hline & & & & \\
\hline & no & no & no & yes \\
\hline
\end{tabular}

Notes: Sample size is 22,435 . Standard errors are shown in parentheses. Omitted race group is white. Hispanics may be of any race. Sample restricted to children age 6-18, in grades 1-12. Sample excludes individuals with missing values for computer use in school or classified as "other race". SMSA type includes central city of MSA, not in center city but in MSA, not in MSA, and not identified (omitted category). SMSA size categories are: not identified, 100,000-249,999, 250,000-499,999, 500,000-999,999, 1-2.499 million (omitted), 2.5-4.999 million, and greater than 5 million. Income categories are: less than $\$ 5,000$, $5,000-7,499,7,500-9,999,10,000-12,499,12,500-14,999,15,000-19,999,20,000-24,999$ 25,000-29,999, 30,000-34,999, 35,000-39,999, 40,000-49,999, 50,000-59,999, $60,000-74,000$, and 75,000 or higher (omitted category), and income not reported. 
Table 7: Percent of workers who use a computer at work, 1997

\begin{tabular}{crr} 
Percent & Standard Error & \multicolumn{1}{c}{ Sample Size } \\
50.63 & 0.2 & 56,247 \\
52.06 & 0.2 & 48,553 \\
40.47 & 0.7 & 4,930 \\
51.46 & 1.1 & 2,128 \\
37.02 & 1.9 & 636 \\
30.33 & 0.7 & 4,675
\end{tabular}

Sample includes employed persons aged 18 to 64 and excludes those classified as "other" race. Hispanics may be of any race 
Table 8: Uses of computers at work in 1997, by Race and Hispanic Origin

Percent of Workers who use a Computer for Various Tasks

\begin{tabular}{lrrrrrr} 
& All Races & White & \multicolumn{3}{c}{ Black } & \multicolumn{4}{c}{ American } \\
Word Processing & 57.1 & 57.5 & 51.9 & 60.4 & 51.4 & 49.9 \\
Calendar/Scheduling & 37.7 & 38.0 & 36.0 & 35.1 & 41.8 & 33.8 \\
Email/Communications & 47.1 & 47.4 & 43.5 & 50.7 & 39.8 & 40.6 \\
Bookkeeping & 30.2 & 31.0 & 24.3 & 24.7 & 26.2 & 24.4 \\
Customer records \& accounts & 50.8 & 51.6 & 46.7 & 42.7 & 49.6 & 49.4 \\
Inventory Control & 28.8 & 29.2 & 27.7 & 22.1 & 30.1 & 31.9 \\
Invoicing & 24.1 & 24.7 & 19.6 & 20.3 & 24.5 & 23.3 \\
Sales \& Marketing & 22.1 & 22.9 & 17.3 & 15.3 & 19.8 & 18.9 \\
Desktop Publishing & 15.3 & 15.8 & 12.4 & 10.7 & 20.7 & 10.9 \\
Graphics \& Design & 20.5 & 21.0 & 16.3 & 18.8 & 24.8 & 16.2 \\
Analysis & 26.9 & 27.4 & 20.8 & 31.8 & 23.9 & 21.3 \\
Programming & 15.1 & 15.0 & 14.0 & 20.4 & 13.0 & 10.5 \\
Spreadsheets & 32.6 & 33.2 & 26.2 & 34.4 & 25.2 & 24.4 \\
Databases & 34.2 & 34.5 & 29.4 & 37.7 & 36.4 & 27.1 \\
Other & 12.6 & 12.7 & 12.5 & 10.8 & 12.2 & 12.1 \\
& & & & & & \\
Sample Size & 28,762 & 25,433 & 2,016 & 1,076 & 237 & 1,407
\end{tabular}

Notes: Sample includes employed persons aged 18 to 64 and excludes those classified as "other" race. Sample includes only persons who report directly using a computer at work. Hispanics may be of any race. The sum of the percentages exceed 100 because individuals could report multiple tasks. 
Appendix Table 1a: Standard Errors for Table 1

$\begin{array}{lrrrr} & 1984 & 1989 & 1993 & 1997 \\ \text { All Grades } & & & & \\ \text { All Races } & 0.30 \% & 0.30 \% & 0.30 \% & 0.30 \% \\ \text { White } & 0.30 \% & 0.40 \% & 0.30 \% & 0.30 \% \\ \text { Black } & 0.60 \% & 0.80 \% & 0.90 \% & 0.80 \% \\ \text { Asian } & \mathrm{n} / \mathrm{a} & 1.90 \% & 1.60 \% & 1.50 \% \\ \text { American Indian } & \mathrm{n} / \mathrm{a} & 2.70 \% & 2.20 \% & 2.10 \% \\ \text { Hispanic } & 0.90 \% & 1.10 \% & 1.00 \% & 0.90 \% \\ & & & & \\ \text { Grades 1-8 } & & & & \\ \text { All Races } & 0.40 \% & 0.40 \% & 0.40 \% & 0.30 \% \\ \text { White } & 0.40 \% & 0.40 \% & 0.40 \% & 0.30 \% \\ \text { Black } & 0.80 \% & 1.00 \% & 1.00 \% & 1.00 \% \\ \text { Asian } & \mathrm{n} / \mathrm{a} & 2.30 \% & 1.90 \% & 1.80 \% \\ \text { American Indian } & \mathrm{n} / \mathrm{a} & 3.00 \% & 2.50 \% & 2.30 \% \\ \text { Hispanic } & 1.10 \% & 1.30 \% & 1.20 \% & 1.10 \% \\ & & & & \\ \text { Grades 9-12 } & & & & \\ \text { All Races } & 0.50 \% & 0.60 \% & 0.60 \% & 0.50 \% \\ \text { White } & 0.50 \% & 0.60 \% & 0.70 \% & 0.60 \% \\ \text { Black } & 1.20 \% & 1.60 \% & 1.70 \% & 1.50 \% \\ \text { Asian } & \mathrm{n} / \mathrm{a} & 3.60 \% & 3.20 \% & 2.90 \% \\ \text { American Indian } & \mathrm{n} / \mathrm{a} & 5.70 \% & 5.10 \% & 4.10 \% \\ \text { Hispanic } & 18.00 \% & 2.20 \% & 2.00 \% & 1.70 \%\end{array}$


Appendix Table 1b: Sample Sizes for Table 1

$\begin{array}{lrrrr} & 1984 & 1989 & 1993 & 1997 \\ \text { All Grades } & & & & \\ \text { All Races } & 25,046 & 24,291 & 23,521 & 22,435 \\ \text { White } & 21,568 & 19,931 & 19,090 & 18,109 \\ \text { Black } & 3,478 & 3,331 & 3,141 & 3,023 \\ \text { Asian } & 0 & 682 & 871 & 868 \\ \text { American Indian } & 0 & 347 & 419 & 435 \\ \text { Hispanic } & 1,895 & 1,964 & 2,214 & 2,639\end{array}$

\section{Grades 1-8}

All Races

16,936

17,271

$16,728 \quad 15,332$

White

14,504

14,106

13,520

12,352

Black

Asian

$2,432 \quad 2,404$

492

$2,241 \quad 2,089$

American Indian

Hispanic

$269 \quad 327 \quad 300$

1,387

1,466

1,599

1,880

Grades 9-12

All Races

$\begin{array}{rrrr}8,110 & 7,020 & 6,793 & 7,103 \\ 7,064 & 5,825 & 5,570 & 5,757 \\ 1,046 & 927 & 900 & 934 \\ 0 & 190 & 231 & 277 \\ 0 & 78 & 92 & 135 \\ 508 & 498 & 615 & 759\end{array}$

White

Black

Asian

American Indian

Hispanic 